\title{
Ambivalent Gender Identities in Contemporary African Literature: A Butlerian Perspective
}

\author{
Léonard KOUSSOUHON
}

Full Professor at the English Department

E-mail:koussouhon@yahoo.com

Fortuné AGBACHI (Corresponding author)

English Department

E-mail: fortune_olusegun@ymail.com

FLASH, University of Abomey-Calavi, BENIN

Laboratory for Research in Linguistics and Literature (LabReLL)

Received: May 5, 2016 Accepted: May 30, 2016 Published: June 6, 2016

doi:10.5296/jsel.v4i1.9558 URL: http://dx.doi.org/10.5296/jsel.v4i1.9558

\begin{abstract}
This paper is an attempt to examine the way male and female participants perform gender in 03 novels, Everything Good Will Come (2006), Swallow (2010) and A Bit of Difference (2013), by a contemporary Nigerian writer called Sefi Atta. The study draws on Gender Performative Theory as developed by the feminist Butler (1990/1999). This theory considers gender identities as being socially constructed. The study highlights the multiple ways in which male and female participants perform gender according to established social norms in the selected novels. Regarding the existing social norms in Nigeria, the findings by scholars like Fakeye, George and Owoyemi (2012), Mejiuni and Awolowo (2006), Bourey et al (2012), Gbadebo, Kehinde and Adedeji (2012), Okunola and Ojo (2012) exude that men are traditionally portrayed as career people, assertive, powerful and active, independent and violent while women are stereotypically depicted as housewives, submissive, powerless and passive, dependent and non-violent (or victims). Based on the above dichotomies between men and women, the study unveils the ideology that underpins gender performances in the novels.
\end{abstract}

Keywords: Gender performative theory, Social norms, Male, Female, Gender identities, Ideology 


\section{Introduction}

The rise of language and gender studies in the 1970s includes the works by well-known scholars like Butler (1990/1999), Eckert and McConnell-Ginet (1992), Cameron (1990; 1997; 1998), Holmes and Meyerhoff (2003), Tannen (2003) and many others. Four main ways of approaching language and gender studies have guided the works by the feminist scholars: deficit approach, dominance approach, difference approach and social constructivist approach. While the dominance and deficit approaches emphasize women's deficiency, weakness and passivity in interaction, the (cultural) difference approach explains the differences in men's and women's language use in relation to their early socialization. The social constructivist or dynamic approach regards gender as being performative or socially constructed in interaction.

The current study draws on the social constructivist approach as developed by Butler (1990/1999) in her gender performative theory. Her theory considers gender identity as only established by one's acts or deeds, or what one does repeatedly according to the existing social or cultural norms. In short, this paper highlights the multiple ways in which male and female participants perform gender according to established social norms in the contemporary Nigerian writer Sefi Atta's novels Everything Good Will Come, Swallow and A Bit of Difference.

\section{Butler's Gender Performative Theory}

According to Boesten (2010), Butler is "one of the most influential feminist theorists of contemporary times". Her works - mostly regarded as contributions to feminist criticismdeal with gender, sex, sexuality, embodiment, vulnerability, etc. Butler (2006) -cited in Roininen (2008: 15) - claims not to be a poststructuralist but a queer theorist. Indeed, queer theorists refer to an influential group in today's feminist environment, which focuses on sexualities, recognition of queer people's rights and deconstruction of heteronormativity or social norms. Our main concern in Butler's theory is not her notion of sex, sexuality, embodiment and others, but her construction of gender as performance. Her famous work entitled Gender Trouble -published in 1990 and reprinted in 1999- suggests a type of feminist criticism, which she terms a "genealogical critique". In Brady and Schirato (2011: 30), a "genealogical critique" means an "enquiry into, and critique of, the terms by which the category of women comes to have any currency as a meaningful cultural category". This signals that Butler's theory of gender performance lays a special emphasis on the portrayal of women in society. Her view of gender problematizes the widespread conception of gender as a result of natural sex differences. She draws on the feminist critic Simone de Beauvoir's renowned mantra -i.e., holy word in meditation in Hindu and Buddhist religious practice- in The Second Sex (1972: 295): “One is not born, but rather becomes, a woman". According to her, gender roles are not assigned from birth since they are socially constructed in the course of time. She refers to gender as a doing, practice or act, one performs in order to become a man or a woman. In other words, in Gallacher (2005: 28), "becoming a man or a woman is a constant repeated performance". Taking into account Butler (1990), Roininen (2008) underscores: 
...nothing in our physical bodies predicts our social behaviour and our experiences of the world. There is no single and stable way of being a man or a woman; it is always situational, tied to the time and the place and the person's particular circumstances. Any attempt to pin down a firm set of characteristics for a woman or man fails because of its absurdity, and reveals only the variation of ways of being, doing and wanting among human beings. (p.36)

Roininen emphasizes gender as being unpredictable, socially experienced or constructed and as allowing multiple and flexible practices or ways of performing male and female gender. These various ways of doing gender, defy established norms regarding the portrayal of women or the dichotomies between men and women.

Beauvoir's The Second Sex refers to dichotomies between men and women as two distinct or clearly defined categories where women are continually subordinated to men. Butler quite rejects this feminist concept of gender roles as status quo, which sticks blindly to contrasting categories. She rather suggests that one should look at the way these categories are socially constructed and provide the reason why one category ranks supreme and the other does not. She thinks one should always question both categories of gender roles. Although gender categories are still valid with Butler's theory, she claims that women refer to a variety of gender identities that one should not reduce to a 'single' category while working in the framework of gender categories.

Regarding the traditional difference between 'gender' and 'sex' as two distinct concepts, Butler (1990) underlines:

Originally intended to dispute the biology-is-destiny formulation, the distinction between sex and gender serves the argument that whatever biological intractability sex appears to have, gender is culturally constructed: hence, gender is neither the causal result of sex nor as seemingly fixed as sex. (p.82)

Butler disapproves of the traditional distinction between 'gender' and 'sex'. She views sex and gender as a result of one's practices. She refers to both as social, cultural and political products -despite the physical differences between male and female through the outward show of the genitals. She argues that only social, cultural and political factors help to assign meaning as to the physical differences between them. In their work, Understanding Judith Butler, Brady and Schirato (2011: 34) state that "sex as a material or embodied difference between male and female only has meaning within the cultural framework that in the sex/gender distinction it is otherwise imagined to precede". In short, the meaning of a baby's genital as male or female is understood -in Rognstad's terms- "within a gendered framework that are socially constructed" (Rognstad, 2012: 12). On her concept of gender, Butler (1988) notes:

Gender is not passively scripted on the body, and neither is it determined by nature, language, the symbolic, or the overwhelming history of patriarchy. Gender is what is put on, invariably, under constraint, daily and incessantly, with anxiety and pleasure. (p.526)

As said earlier, in Butler's theory, gender is not something fixed. It refers to a performed role, which is continually created by one's interactions with others and one's reactions to those 
interactions. This suggests that one is made to perform gender. For a better understanding of Butler's theory, we must have a close look at her concept of performativity in connection with gender roles. The concept of performativity views gender as performance. Butler's notion of performance has nothing to do with an artistic presentation. It concerns "something one does, rather than something one is" (Rognstad, 2012: 17). Thus, gender identity is only established by what "one does" -i.e., one's acts or deeds. The word gender signals no gender identity in itself. Butler (1990) further argues:

"Performativity is not a singular act, but a repetition and a ritual, which achieves its effects through its naturalization in the context of a body, understood, in part, as a culturally sustained temporal duration." (p.15)

In other words, people initially learn to perform gender owing to repeated acts. Through repetition, they naturalize their gender performance. Once their gender performance is naturalized, it is said to be biologically constructed -instead of culturally or socially constructed. Besides, gender performance does not depend solely on the actor. It also depends on social or cultural norms. As a result, Brady and Schirato (2011) claim:

Every performance of gender is required by the histories of gender intelligibility to cite the norms that precede and produce it, and that the ongoing requirement of gender performance requires the ongoing and repeated citations of those norms. (p.48)

From birth, people are exposed to the existing norms as to their performance of gender. Hence, they perform gender in relation to those norms as intelligible genders or participants in the gender they belong to. Someone is regarded as intelligible in his / her gender identity when he / she fits in the existing structures, norms and practices of his / her identity. Butler (1990/1999) considers practices that do not fall into the category of male or female as unintelligible gender identities. She refers to practices undertaken by gays, lesbians or people with sexual desires not conforming to existing heterosexual norms, etc. In short, as gender can be performed intelligibly or unintelligibly, Deforest (2011: 5) highlights gender as "a performance that can be undermined by performances that fail to conform to societal norms".

The notion of representation in Butler's theory is a functional term, which consists in providing visibility for individuals within their social context. It identifies his / her acceptable or inacceptable practices; explains how the individual, 'subject' or 'agent' -in Butler's terms (1990/1999) - performs gender and reveals normativity -i.e., what is normal or abnormal. One crucial element in normativity is the context in which the individual arises. In other words, norms applied in Butler's theory have to be carried out according to the context in which the individuals or participants develop. According to her, cultures and social norms give rise to expectations for appropriate gender performances and define ways of ensuring that those expectations are repeatedly met. This provides a way to investigate the normative representation of male and female participants in Sefi Atta's novels. The current study on her novels, takes place within an African setting and especially in Nigeria.

We have chosen to focus our analysis of the representation of Butler's theory of performative gender on different dichotomies between Nigerian men and women. These dichotomies have 
been drawn from the scientific works done mainly by Nigerian scholars on some gender norms or social norms in Nigeria. Thus, the findings of such scholars as Fakeye, George and Owoyemi (2012), Mejiuni and Awolowo (2006), Bourey et al (2012), Gbadebo, Kehinde and Adedeji (2012), Okunola and Ojo (2012) have been of paramount importance to the current paper. The dichotomies used appear as follows: career person versus housewife, assertive versus submissive, powerful and active versus powerless and passive, independent versus dependent and violent versus non-violent. More details will be given next.

\subsection{Career Person versus Housewife}

Traditionally, a career person or a professional working person is viewed as a masculine characteristic while a housewife has a feminine connotation. Similarly, Fakeye, George and Owoyemi (2012) specify the Nigerian's condition in their work:

Traditionally in Africa (Nigeria inclusive), women have no role in the society aside from raising children and household chores, they are relegated to the background as they are ignorant of their legal rights or unable to claim those rights even when they are aware of them. (p.134)

The representation of the main participants as career person or housewife -according to Butler's theory-in the three novels will be examined in the following section.

\subsection{Assertive versus Submissive}

Stereotypically, men are considered as assertive while women are submissive. The Nigeria's situation is revealed throughout the work by Mejiuni and Awolowo (2006) as follows:

...the beauty of a woman is actually in submission. [...] female achievers usually forget that the beauty of their achievements is having a cover over their heads and the cover is their husbands. The beauty of a woman is submitting to the authority of a husband even if the authority is a dummy. (p.162)

The analysis of representation of male and female participants as assertive or submissive in the three novels will be of great interest in the next section.

\subsection{Powerful and Active versus Powerless and Passive}

By tradition, men are depicted as powerful and active while women are powerless and passive. So, men have the power to make decisions and implement them to the detriment of women. Bourey et al (2012: 1) explore gender norms and power in sub-Saharan Africa. Their work shows the following: "Power within sexual relationships [...] refers to the ability of one partner to dominate decision-making, control the other partner, engage in actions against the other partner's wishes."

By the same token, Gbadebo, Kehinde and Adedeji (2012: 13) study women's participatory roles in Nigeria and come to the conclusion that "Women in particular are frequently excluded from decision making either in the household or community level through representative systems of community institutions and organizations." The representation of male and female participants as powerful and active or powerless and passive, in the three novels, is analysed in the next section. 


\subsection{Independent versus Dependent}

Seen stereotypically as mentally and physically strong, men are the ones who need to come to women's rescue. Hence, men are viewed as independent while women are dependent. In their work, Bourey et al (2012: 1) underline this fact: "Power within sexual relationships [...] refers to the ability of one partner to [...] effectively act independently of the relationship." The way Sefi Atta represents male and female participants as independent or dependent, in the three novels, will be highlighted in the following section.

\subsection{Violent versus Non-violent}

Stereotypically, men are seen as violent -being the ones who exert acts of violence on women- while women are considered as non-violent -being the victims of men's violent actions. Okunola and Ojo (2012) have carried out:

... a research investigation of violence against women in a selected place in the Western part of Nigeria. The results show that women's rights are still being violated in areas of physical assault, sexual assault, economic extortion, widowhood and inheritance sharing. (p.131)

The analysis of the representation of male and female participants as violent or non-violent, according to Butler's theory, stands for the last issue to be raised in Sefi Atta's novels.

\section{Qualitative Analysis of Butler's Theory of Gender Representation in Sefi Atta's Novels}

The qualitative analysis of Butler's theory of gender representation is carried out here -in each analysed novel-according to the following dichotomies: career person versus housewife, assertive versus submissive, powerful and active versus powerless and passive, independent versus dependent and violent versus non-violent. The representation of male and female participants is displayed in bold in the clauses/sentences where it appears.

\subsection{Qualitative Analysis of Butler's Theory of Gender Representation in 'Everything Good Will Come'}

This subsection is devoted to Butler's theory of gender representation in Everything Good Will Come based on the dichotomies stated above. The analysis is focused on the way Sefi Atta chooses to represent the main character Enitan and other characters like: Enitan's mother, Enitan's father, Enitan's husband, Enitan's girlfriend, etc.

\subsubsection{Representation of Career Person versus Housewife in Everything Good Will Come}

Clauses/sentences $(1,2,3,4,5)$ represent both male and female participants as career people:

1- My mother vowed to have my father disbarred (p.79); 2- working as a shop assistant in department stores (p.79); 3- Monday, after the parade, I started work at my father's firm (p.120); 4Look at her, good hostess, lawyer, and all that (p.128); 5- I was at work when I felt the first contraction (p.185).

Sentence (1) implicitly shows that Enitan's father is a lawyer. As a result, Enitan's mother 


\section{Macrothink Institute ${ }^{T M}$}

"vowed" "to have" him "disbarred". In $(2,3,4,5)$, Enitan is continually depicted as "a shop assistant", a "lawyer" at her "father's firm" or "at work".

Clauses/sentences $(6,7,8,9,10)$ represent female participants as housewives:

6- Good women were at home (p.155); 7- he said I would have to perform my wifely duties (p.201);

8- You must take care of your husband's home (p.204); 9- and for a man who won't even take a glass to the kitchen (p.204). 10- The man behaves as if I'm his personal servant (p.204).

Sentence (6) depicts "good women" as housewives: "at home". In (7, 8, 10), Enitan is expected to be a housewife through such expressions as: "perform...wifely duties", "take care of...husband's home" and "as if I'm his personal servant". Clause (9) illustrates no man as househusband in Everything Good Will Come: they are portrayed as the ones "who won't even take a glass to the kitchen".

\subsubsection{Representation of Assertive versus Submissive in Everything Good Will Come}

Clauses/sentences $(11,12,13,14,15,16,17,18)$ represent both male and female participants as assertive:

11-A woman should have more comportment (p.130); 12-"This is my house," I heard him say (p.130); 13-In my 29 years no man ever told me to show respect (p.184); 14-And the expectation of subordination bothered me most (p.184); 15-How could I defer to a man whose naked buttocks I'd seen? Touched? (p.184); 16-Obey him without choking on my humility, like a fish bone down my throat (p.184); 17-He is the head of the house. He has the right to know (p.294); 18-I was not looking for a compromise (p.317).

In sentence (11), "a woman" is expected to be assertive: "should have more comportment". Sentences $(12,17)$ show Enitan's father and Enitan's husband as assertive in: "This is my house", "the head of the house... has right to know". Clauses in $(13,14,15,16,18)$ posit the female character Enitan as assertive in such expressions as: "no man ever told me to show respect", "the expectation of subordination bothered me most", "How could I defer to a man...?", "Obey him without choking on my humility", and "was not looking for a compromise".

Clauses/sentences $(19,20,21,22)$ represent female participants as submissive:

19-Good women didn't shout in somebody's house (p.155); 20-how women respected men and ended up shouldering burdens (p.184); 21-that a woman makes sacrifices in life (p.294); 22-It shouldn't take anything out of you to indulge your husband for the sake of peace in your house (p.294).

In $(19,20,21,22)$, “(good) women" and Enitan are expected to be submissive by respecting "men", making "sacrifices in life", indulging their "husband for the sake of peace" and not shouting "in somebody's house".

3.1.3 Representation of Powerful and Active versus Powerless and Passive in Everything Good Will Come 


\section{Macrothink}

Clauses/sentences $(23,24,25)$ represent Enitan as powerful and active:

23-I want them out of my house (about her in-laws) (p.213); 24-My husband asked why I was leaving him (p.323); 25-What kind of woman are you? (p.323).

The above clauses/sentences show Enitan as a powerful and active woman in the expressions "want them out of my house", "My husband asked why I was leaving him" and "What kind of woman are you?". Enitan is referring to her in-laws in (23).

Clauses/sentences $(26,27)$ represent a male participant as powerless and passive:

26-He can't keep a family together now he wants to save his country (p.220); 27-My father couldn't even save himself (p.220).

Clauses/sentences $(26,27)$, about Enitan's father, illustrate a powerless and passive man in: "can't keep a family together" and "couldn't even save himself".

\subsubsection{Representation of Independent versus Dependent in Everything Good Will Come}

Clauses/sentences $(28,29,30,31)$ represent female participants as independent:

28-If only the women themselves could read the books, critique them: this is right; this is incorrect; this is total nonsense (p.256); 29-that I didn't know how to think like an African woman. I only knew how to think for myself (p.287); 30-but I decided against it. Everyone must walk their own path unencumbered (p.310); 31-I'm not one of those who believe in crying to the West (p.314).

In sentence (28), women are expected to be independent by reading "the books", discussing and commenting on "them" or by developing a critical attitude. Clauses/sentences $(29,30,31)$ show Enitan as independent through such expressions as: "I only knew how to think for myself", "I decided against it. Everyone must walk their own path", "I'm not one of those who believe in crying to the West".

Clauses/sentences $(32,33,34)$ represent the female character Enitan as dependent:

32-and I don't think you should be making yourself so available to a man you've just met (p.130); 33-And you can stop following him outside unchaperoned, for a start (p.130); 34-But you were wrong not to consult your husband first (p.294).

Clauses/sentences $(32,33)$ put on view Enitan as being dependent on her husband in the following expressions: "I don't think you should be making yourself so available to a man" and "you can stop following him outside unchaperoned". As for sentence (34), Enitan is expected to be dependent on her husband's advice as follows: "you were wrong not to consult your husband first".

3.1.5 Representation of Violent versus Non-violent in the Selected Excerpts from Everything Good Will Come

Clauses/sentences $(35,36)$ represent male participants as violent:

35-how he ignored her in public (p.79); 36-Niyi was wrong. To ignore your wife because she made a mistake like that (p.294). 
In $(35,36)$, Enitan's father and Enitan's husband respectively show some violent traits by disregarding their wives as follows: "ignored her in public" and ignore her "because she made a mistake like that".

Clauses/sentences $(37,38,39,40)$ represent female participants as non-violent:

37-Instead she developed hypertension and said my father had caused it (p.79); 38-and she spent most of them complaining about him (p.79); 39-Good women didn't fight on the streets (p.155); 40-to treat a woman like a person (p.276).

In $(37,38)$, Enitan's mother is depicted as non-violent or as a victim of Enitan's father's behaviour: "she developed hypertension" and "spent most of" her time "complaining". In clause (39), "good women" are expected to be non-violent or tolerant by not fighting "on the streets". Clause (40) confirms that a woman is victimized or treated unfairly as a non-violent person.

\subsection{Qualitative Analysis of Butler's Theory of Gender Representation in 'Swallow'}

The current subsection accounts for Butler's theory of gender representation in Swallow according to the dichotomies in section 3. The analysis considers the way Sefi Atta chooses to represent the main character Tolani and such characters as Tolani's mother, Tolani's girlfriend, Tolani's boyfriend, etc.

\subsubsection{Representation of Career Person versus Housewife in Swallow}

Clauses/sentences $(41,42)$ represent some female participants as career women:

41-working as a secretary in a bank (p.10); 42-In our home, I was earning more money than he was from cloth dyeing (p.127).

In the above clauses/sentences, Tolani and her mother are depicted as career women. Tolani is "working as a secretary in a bank" and her mother, a successful businesswoman, greatly contributes to household.

Clauses/sentences $(43,44)$ represent some female participants as housewives:

43- Women traded and elders watched over children (p.38); 44- There was no flesh on Mama Chidi, because she was looking after so many children, all under the age of eleven (p.97).

In $(43,44)$, women and especially "elders" are portrayed as housewives: "elders watched over children", "she was looking after so many children, all under the age of eleven".

\subsubsection{Representation of Assertive versus Submissive in Swallow}

Clauses $(45,46)$ represent female participants as assertive:

45-I am taking my vacation from next week, Mr. Salako (p.231); 46-She was almost a man (p.272).

Clause (45) presents Tolani as assertive or self-confident. She is taking her "vacation" by stating her position or sharing her decision with her branch manager, Mr. Salako. Clause (46) depicts Tolani's mother as assertive or authoritative: "She was almost a man". 


\section{Macrothink}

Clauses $(47,48,49)$ represent Tolani's mother as submissive:

47-and hers was sacrifice (p.293); 48-She could have had more children (p.293); 49-She could have exposed him (p.293).

In the above clauses, Tolani's mother is portayed as a submissive woman. She suffers silently though imperfectly for her husband's sterility by making "sacrifice", by not having "more children" and by not exposing "him".

\subsubsection{Representation of Powerful and Active versus Powerless and Passive in Swallow}

Clauses/sentences $(50,51,52)$ represent Tolani's mother as powerful and active:

50-Now, if a woman neglects or mistreats her child, then I must talk (p.269); 51-She settled arguments between neighbours (p.272); 52-She made him prostrate before the accused's parents (p.272).

Clauses/sentences $(50,51)$ show Tolani's mother as a powerful and active woman especially in decision-making: she "must talk" when "a woman neglects or mistreats her child", she "settled arguments between neighbours". In sentence (52), she acts powerfully on a guilty male by making "him prostrate before the accused's parents".

Clauses/sentences $(53,54)$ represent the female participant Tolani as powerless and passive:

53-to think that this was how our relationship ended (p.284); 54-thinking about how I'd almost paid him to marry me (p.285).

In $(53,54)$, Tolani is portrayed as powerless and passive at a breaking point in her relationship with her boyfriend: "to think that this was how our relationship ended" and "thinking about how I'd almost paid him to marry me".

\subsubsection{Representation of Independent versus Dependent in Swallow}

Sentence (55) represents male participants as independent:

55-If a man is sterile no one has to know (p.203).

In the above clause, men are perceived as independent, self-governed or not controlled by others, especially women. Thus, a sterile man is in no way to blame or to be known.

Clauses/sentences $(56,57,58)$ represent some female characters as dependent:

56-You know that if a woman is infertile she can't hide it (p.203); 57-To come home without money was bad enough, and now I might have to depend on her (p.280); 58-Instead, she enjoyed freedoms that other women envied, freedoms that belonged to her (p.293).

In $(56,57)$, “a woman" or Tolani's mother is constructed as dependent on her husband or controlled by him. Hence, her infertility cannot be hidden and her freedom is restricted. In (58), Tolani is considered as (potentially) dependent on her mother: "I might have to depend on her".

\subsubsection{Representation of Violent versus Non-violent in Swallow}




\section{$\triangle$ Macrothink}

Journal for the Study of English Linguistics

ISSN 2329-7034

2016, Vol. 4, No. 1

Clauses/sentences $(59,60,61,62,63)$ represent both male and female participants as violent:

59-Rose and I were to swallow condoms of cocaine. OC said (p.211); 60-I have been to the babalawo (p.231); 61-They have given me a potion (p.231); 62-If you sack me, your own job will be in jeopardy, your life at home will spoil (p.231); 63-Disappear. I don't care where you go, just don't come back (p.248).

In $(59,63)$, the male participant $\mathrm{OC}$ is portrayed as violent being the instigator of drug dealings by women, which finally leads to Tolani's girlfriend's death and Tolani's return home. In $(60,61,62)$, Tolani is depicted as violent, when she threatens her branch manager with "a potion" from a so-called "babalawo" in the following expression: "If you sack me, your own job will be in jeopardy, your life at home will spoil".

Clauses/sentences $(64,65)$ represent female participants as non-violent:

64-If we spoke a word about his plan, we would both disappear (p.212); 65-The bags burst inside her. She perished on a plane yesterday night (p.246).

In the above clauses/sentences, Tolani and her late girlfriend are depicted as non-violent or as the victims of a male dealer, who threatens them: if they "spoke a word about his plan", they "would both disappear".

\subsection{Qualitative Analysis of Butler's Theory of Gender Representation in 'A Bit of Difference'}

This last subsection, related to Butler's theory of gender representation in A Bit of Difference, is focused on the dichotomies in section 3. The analysis is interested in the way Sefi Atta represents the main character Deola and other characters like Deola's mother, Deola's sister, Deola's boyfriend, etc.

\subsubsection{Representation of Career Person versus Housewife in A Bit of Difference}

Clauses/sentences $(66,67,68)$ represent both male and female participants as career people:

66-Funsho works for a telecommunication company and their headquarters is in Johannesburg (p.56); 67-As an auditor, she can cope with her clients' habits (p.175); 68-You young women, Subu's mother is saying. You work too hard. You worked hard in your day (p.220).

Clause (67) presents the female character Deola as a career woman: "an auditor". Clause (66) implicitly refers to Funsho -Deola's sister's husband- as a career person: he is an employee in a "telecommunication company" whose headquarters "is in Johannesburg", South Africa. Sentences (68) depict today's "young women" as hard-working or career women in contrast to yesterday's women.

Clauses $(69,70,71)$ represent some female participants as housewives:

69-and has left Lulu and Prof with her mother (p.180); 70-She may not be very modern in thinking (p.188); 71-that Lulu and Prof are with her mother-in-law (p.199).

In clauses $(69,71)$, Deola's mother and Deola's sister's mother-in-law look after their grandchildren at home. They act as housewives. Besides, Deola's sister's mother-in-law is 
portrayed as a typical traditional woman in (70).

\subsubsection{Representation of Assertive versus Submissive in A Bit of Difference}

Clauses/sentences $(72,73,74,75,76)$ represent both male and female participants as assertive:

72-that Bandele, the biggest snob she knows loved a steward because the steward was nice to him (p.171); 73-Why didn't you just tell me you were gay? (p.172); 74-She wants a separation without family interference (p.180); 75-You have to know how to defend yourself (p.180); 76-I don't know what makes you think you can tell a man you are not interested in marrying him or meeting his family (p.188).

In (76), Deola makes the following assertive claim: she tells "a man"-i.e., the man who got her pregnant- that she is not "interested in marrying him or meeting his family". Clauses/sentences $(72,73)$ show a male participant as assertive. As "the biggest snob" Deola "knows", he feels superior and looks down on others. In contrast, he is "a gay" who acts secretly or does not assert himself as seen in: "didn't...tell...you were gay". Sentence (74) describes Deola's sister as assertive in her wish for marital life. She "wants a separation without family interference". In (75), Deola or her sister is expected to be assertive by knowing "how to defend" herself.

Clauses/sentences $(77,78)$ represent both male and female participants as submissive:

77-You don't give a man the impression he is not needed (p.188); 78-Just because your father gave you this house, you think you can treat my son like a woman (p.199).

In (77), Deola is expected to be submissive by showing deference to her boyfriend or acknowledging his authority in the expression: “don't give a man the impression he is not needed". Sentence (78) implicitly suggests that Deola's sister's husband has some submissive traits. He lives in Deola's sister's house and Deola's sister treats him "like a woman".

3.3.3 Representation of Powerful and Active versus Powerless and Passive in A Bit of Difference

Clauses/sentences $(79,80,81,82)$ represent both male and female characters as powerful and active:

79-to be in a position to hold sway at home, first as wife and now as a sort of dowager (p.188); 80-I know you are very capable of doing just that (p.188); 81-and another who orders her husband out of their house, when she knows the sort of family he is coming from (p.188); 82-Her husband was highly regarded in their circle ( $\mathrm{p} .188)$.

Following her husband's death, Deola's mother is portrayed as a powerful and active woman "at home" -in (79). Sentence (80) presents Deola as a powerful and active woman who is "very capable of doing just that". In (81), Deola's sister proves to be powerful and active by ordering "her husband out of their house". Meanwhile, clause (82) depicts her father-in-law as a powerful or influential man who is said to be "highly regarded in their circle". 
Sentence (83) represents a male participant as powerless and passive:

83-I told him that if he dared, just dared to lift his hand, he would never forget what I would do to him (p.199).

The above sentence implicitly shows Deola's sister's husband as powerless and passive before her wife's threat to retaliate as follows: "if he dared, just dared to lift his hand, he would never forget what I would do to him".

3.3.4 Representation of Independent versus Dependent in the Selected Excerpts from A Bit of Difference

Clauses/sentences $(84,85,86,87,88,89,90,91)$ represent female participants as independent:

84-I'm proud, you know, so proud I turned my back on a whole nationality of men (p.173); 85-she was looking for a job that meant something to her (p.175); 86-Aunty Bisi once admitted she never got married because she didn't want a husband always around and irritating her (p.179); 87-No one will force me to do anything (p.183); 88-Abroad, you can have it all -money, good health and security (p.195); 89-she says. I'm free of that family (p.199); 90-Don't let her or Aunty Bisi push you into anything (p.199); 91-You will have all you want, a good husband and children (p.220).

In (84), Deola takes great pride in being independent of "a whole nationality of men". Sentence (85) shows Deola as someone who seeks self-satisfaction and who is not dependent on "a job" that does not mean "something to her". In $(87,90)$, Deola is expected or pretends not to be controlled especially by her mother and Aunty Bisi. In $(88,91)$, Deola is expected or promised to be fully independent "abroad", where she "can have... all" she wants like "a good husband and children". In (86), Aunty Bisi seeks her independence from men by not getting "married" to "a husband" "always around" to irritate her. In (89), Deola's sister claims her independence from her in-laws as follows: "I'm free of that family".

Clauses/sentences $(92,93)$ represent both male and female characters as dependent:

92-how much her trip to Nigeria woke her up to the fact that she misses home and she ought to go back for good instead of contributing to the brain drain (p.175); 93-I'm prepared to do anything, anything you want (p.183).

In (92), Deola is dependent on "home" -i.e., Nigeria- and especially Lagos. This is the reason why "she ought to go back for good instead of contributing to the brain drain". Sentence (1552) depicts Deola's husband as dependent on her uncontrollable wish. This leads him to say: "I'm prepared to do anything, anything you want".

\subsubsection{Representation of Violent versus Non-violent in A Bit of Difference}

Clauses/sentences $(94,95)$ represent a female participant as violent:

94-but you cannot insult her family and get away with that (p.188); 95-She said I was rude to him (p.199).

In $(94,95)$, Deola's sister is depicted as violent or insensitive in speech. She has insulted a 
whole "family" -i.e., her in-laws- and has been "rude" to her husband.

Clause (96) represents a male participant as non-violent:

96-How I abused him in front of his mother (p.199).

In clause (96), Deola's sister's husband is implicitly portrayed as non-violent or a victim of his wife, who "abused him in front of his mother".

\section{Discussion of Findings}

Basically, in the analysis of the normative representation of male and female participants in the three novels, Sefi Atta has not used a single or rigid representation for male or female participants regarding their normative representation -as career people, assertive or submissive, powerful and active or powerless and passive, independent or dependent and violent or non-violent. In other words, no single gender is continually portrayed as assertive or submissive, powerful and active or powerless and passive, independent or dependent and violent or non-violent. For instance, the main female characters in the three novels are depicted differently regarding their use of power and their actions. While Sefi Atta portrays Enitan and Deola as powerful and active women, she depicts Tolani as a powerless and passive woman. This complex representation of male or female participants confirms that Sefi Atta does not have a stereotypical representation of male or female participants in her novels. This also shows that Sefi Atta's novels mirror this complex representation of men or women in contemporary African society, where there are assertive, powerful, independent and violent men/women as well as submissive, powerless, dependent and non-violent men/women.

In the three novels, only women are depicted as housewives. This highlights a continuity in the traditional norms whose main defenders -in the analysed clauses/sentences- are: Enitan's husband, her mother-in-law and Deola's sister's mother-in-law, etc. The absence of the explicit representation of male participants as househusbands in the selected excerpts, confirms Sefi Atta's will to stick to the existing social norms -that considers only women as housewives. Nevertheless, Sefi Atta's representation of the main characters -Enitan, Tolani and Deola- and other female characters as career women, indicates social changes in the normative representation of women in contemporary African society. In other words, today's women are not always housewives: they may also be career women.

The expectation of women to be assertive in Everything Good Will Come posits Enitan's father as the defender of change in established norms while the expectation of women to be submissive in Everything Good Will Come and A Bit of Difference, reveals the defenders of traditional norms like Enitan's husband, her mother-in-law, Deola's mother and her aunt Bisi, etc. Sefi Atta especially represents men as powerless and passive in Everything Good Will Come and A Bit of Difference, to show the existence of powerless and passive men in contemporary African society and to prove that power and actions are not the exclusive privilege of men alone. 


\section{Macrothink

The expectation of women to be independent in Everything Good Will Come, discloses the narrator Enitan and implicitly, the writer Sefi Atta as their active defenders. This proves the writer's expectations of freeing women -particularly her female readers- from any dependence. In fact, her female character Enitan's independence, in the novel, is a living example of her expectations. In the same way, the promise of independence to women at the end of A Bit of Difference, confirms the writer's expectations. Sefi Atta's representation of men as non-violent or victims in A Bit of Difference, sheds light on the fact that violent actions are not gender-specific. They can be perpetrated by men or women in contemporary African society. Her representation of a gay man as an unintelligible gender identity -in Butler's terms (1990/1999) - highlights a striking deviation from established social practices or practices that do not fall into the category of male and female participants in contemporary African society.

\section{Conclusion}

This paper has demonstrated how ambivalent gender identities are constructed in contemporary African literature through the normative representation or the gender performances of male and female participants regarding established norms. Indeed, the contemporary writer has constructed gender performances in a way that reveals gender as fluid. And this denotes somehow that she does not hold onto established ideologies regarding the portrayal of women. She has used language in a way that proves language to be the mirror of society, especially contemporary African society, in which there is a complex representation of both men and women.

\section{References}

Atta, S. (2006). Everything Good Will Come. Lagos: Farafina.

Atta, S. (2010). Swallow. Massachussetts: Interlink Books.

Atta, S. (2013). A Bit of Difference. Massachussetts: Interlink Books.

Boesten, J. (2010). Inequality, normative violence and livable life: Judith Butler and Peruvian Reality. Polis Working Papers, (1), 1-22. Retrieved from http://www.polis.leed.ac.uk/assets/files/research/working-papers/working-paper-no1-2010.pd f.

Bourey, C. et al. (2012). Pile sorting innovations: Exploring gender norms, power and equity in sub-Saharan Africa. Global Public Health: An International Journal for Research, Policy and Practice, 1-14. http://dx.doi.org/10.1080/17441692.2012.709259

Brady, A., \& Schirato, T. (2011). Understanding Judith Butler. London: SAGE Publications. http://dx.doi.org/10.4135/9781446269183.n3 
Butler, J. (1988). Performative Acts and Gender Constitution: An Essay in Phenomenology and Feminist Theory. Theatre Journal, 40(4), 519-531. Retrieved from http://www.jstor.org/stable/3207893.

Butler, J. (1990/1999). Gender Trouble: Feminism and the Subversion of Identity. New York: Routledge.

Cameron, D. (1990). The Feminist Critique of Language: A Reader. New York: Routledge.

Cameron, D. (1997). Performing Gender Identity: Young men's talk and the construction of heterosexual masculinity. In Sally Johnson and Ulrike Hanna Meinhof (eds), Language and Masculinity (pp. 47-64). Oxford: Blackwell.

Cameron, D. (1998). Gender, language and discourse. Journal of Women, Culture and Society, 23(4), 945-973. http://dx.doi.org/0.1086/495297

De Beauvoir, S. (1972). The Second Sex. Ed. H.M. Parshley. Harmondsworth: Penguin Books.

Deforest, K. (2011). Imperial Performativity: The life, transgression, and writings of Isabelle Eberhardt under the lens of queer theory. Wyndham Robertson Library Research Awards, 1-21. Retrieved from http://digitalcommons.hollins.edu/researchawards/6

Eckert, P., \& McConnell-Ginet, S. (1992). "Think Practically and Look Locally: Language and Gender as Community-Based Practice". Annual Review of Anthropology, 21, 461-490. http://dx.doi.org/10.1146/annurev.an.21.100192.002333

Fakeye, Y., George, O. J., \& Owoyemi, O. (2012). Women in Purgatory: The Case of Nigerian Women in the Boardrooms. Asian Journal of Business and Management Sciences, 1(10), 134-150. ISSN 2047-2528.

Gallacher, L. (2005). The Psychology of Intersex: Research into the Experiences of Individuals/Parents who have Experienced Androgen Insentivity Syndrome or Congenital Adrenal Hyperplasia within the UK. Unpublished M.A. Thesis. University of York.

Gbadebo, A. M., Kehinde, I. A., \& Adedeji, O. H. (2012). Participatory Roles of Women in Quarrying Activities in Abeokuta Metropolis. Global Journal of Human Social Science, 12(13), 12-25. ISSN 2249-460X.

Holmes, J., \& Meyerhoff, M. (2003). The Handbook of Language and Gender. Oxford: Blackwell Publishing. from http://onlinelibrary.wiley.com/doi/10.1002/9780470756942

Mejiuni, O., \& Awolowo, O. (2006). Confounding or Empowering Women through Non-Formal and Informal Education? Religious Leaders in Ibadan and Lokoja, Nigeria, on Knowledge that Matters. Canadian Association for the Study of Adult Education, 161-166. Retrieved from http://casea-aceea.ca/ casae/sites/casae/archives/cnf2006/2006onlineProceedings/CAS2006O lutoyin\%2520Mejiuni.pdf 


\section{Macrothink}

Journal for the Study of English Linguistics

ISSN 2329-7034 2016, Vol. 4, No. 1

Okunola, R. A., \& Ojo, M. O. D. (2012). Violence Against Women: A Study of Ikire Area of Osun State Nigeria. African Journal of Social Sciences, 2(2), 131-147. ISSN 2045-8460.

Rognstad, M. (2012). The Representation of Gender in Virginia Woolf's Orlando and Jeffrey Eugenides's Middlesex. Unpublished M.A. Thesis. University of Oslo.

Roininen, E. (2008). Doing Gender / Doing Profession in Finnish Working Life. Unpublished Ph.D. Thesis. University of St. Gallen.

Tannen, D. (2003). Gender and Family Interaction. In J. Holmes, \& M. Meyerhoff (Eds.), The Handbook on Language and Gender (pp. 179-201). Oxford, UK \& Cambridge, MA: Basil Blackwell. http://dx.doi.org/10.1002/9780470756942.ch8

\section{Copyright Disclaimer}

Copyright for this article is retained by the author(s), with first publication rights granted to the journal.

This is an open-access article distributed under the terms and conditions of the Creative Commons Attribution license (http://creativecommons.org/licenses/by/3.0/). 